\title{
Depleted serum vitamin E concentrations precede left displaced abomasum in early-lactation dairy cows
}

\author{
Y. Qu, ${ }^{*}$ K. Lytle,† M. G. Traber, †‡ and G. Bobe ${ }^{*}{ }^{1}$ \\ ${ }^{*}$ Department of Animal and Rangeland Sciences, College of Agriculture, and \\ †School of Biological and Population Health Sciences, Oregon State University, Corvallis 97331-4802 \\ fLinus Pauling Institute, Oregon State University, Corvallis 97331-6512
}

\begin{abstract}
Cows with left displaced abomasum (LDA), a costly disease occurring primarily in multiparous dairy cows during early lactation, have been reported to have $40 \%$ lower circulating concentrations of vitamin E. It is unknown, however, whether the lower circulating $\alpha$-tocopherol concentrations precede LDA or remain after LDA. Using a nested case-control design, blood samples taken at d $-21,-14,-7,-3,-1,0,1,3,7$, $14,21,28,35,42$, and 49 postpartum from 7 multiparous Holstein cows diagnosed with LDA between d 6 and 32 postpartum and 10 healthy Holstein cows from the same herd were analyzed for serum concentrations of $\alpha$-tocopherol and indicators of energy and nutrient status and inflammation. In addition to indicators of negative energy balance and inflammation, lower serum $\alpha$-tocopherol concentrations preceded LDA and persisted after LDA correction. At the last blood sampling before LDA diagnosis, cows had serum $\alpha$-tocopherol concentrations $45 \%$ lower $(5.0 \pm 0.9$ vs. $9.1 \pm 0.9 \mu M)$ and $\alpha$-tocopherol to cholesterol molar ratios $39 \%$ lower $(1.90 \pm 0.19$ vs. $3.09 \pm 0.26)$ than those of healthy cows. Serum $\alpha$-tocopherol concentrations remained lower ( $<10$ vs. $\sim 15 \mu M$ ) up to d 49 postpartum in cows that had LDA. These findings indicate that lower serum $\alpha$-tocopherol concentrations are a potential early indicator for the development of LDA in multiparous cows.
\end{abstract}

Key words: dairy cow, early lactation, left displaced abomasum, vitamin E

\section{INTRODUCTION}

Left displaced abomasum (LDA) is an economically important disease that affects approximately $3.5 \%$ of US dairy cows (US Department of Agriculture, 2009). The cost per case, including surgery, milk loss, and mortality, is estimated to be between $\$ 250$ and $\$ 400$

Received November 7, 2012.

Accepted February 2, 2013.

${ }^{1}$ Corresponding author: gerd.bobe@oregonstate.edu
(Bartlett et al., 1995) and does not include costs associated with decreased BW, delayed reproductive performance, or increased culling rates (Østergaard and Gröhn, 1999; Raizman and Santos, 2002). Many factors play a role in the etiology of LDA, including genetics, age ( $>3 \mathrm{yr})$, early lactation, late winter and early spring, obesity, endotoxemia, rapid weight loss, sudden diet changes, high grain and corn silage and low NDF rations, low feed intake, rumen fill, and rumen motility, impaired liver function, pregnancy with multiples, and co-morbidities (reviewed by Geishauser, 1995; Shaver, 1997; Doll et al., 2009). Two major types of LDA are recognized: primary LDA, which occurs throughout lactation in response to feed management errors, and secondary LDA, which occurs in multiparous cows during the first month of lactation as part of the peripartal disease complex. This study focuses on the latter type.

$\alpha$-Tocopherol, the most abundant and biologically active form of vitamin $\mathrm{E}$, is a lipid-soluble antioxidant that prevents oxidation of PUFA (reviewed by Baldi, 2005; Traber and Atkinson, 2007; Politis, 2012). Current National Research Council recommendations for supplemental $\alpha$-tocopherol in dairy cows are 1.6 IU/ $\mathrm{kg}$ of BW (approximately $80 \mathrm{IU} / \mathrm{kg}$ of DMI) during the dry period and $0.8 \mathrm{IU} / \mathrm{kg}$ of $\mathrm{BW}$ (approximately 20 $\mathrm{IU} / \mathrm{kg}$ of DMI) during lactation (NRC, 2001). Dietary vitamin $\mathrm{E}$ requirements are elevated in early lactation because lipid peroxidation is increased (Castillo et al., 2006; Sordillo and Aitken, 2009), significant amounts of vitamin $\mathrm{E}$ are secreted in the colostrum (Weiss et al., 2009), and depressed feed intake, inflammation, and low lipid absorption and transport may decrease dietary vitamin E utilization (Baldi, 2005).

Cows with LDA have $40 \%$ lower circulating $\alpha$-tocopherol concentrations than control cows (Mudron et al., 1997; Hasanpour et al., 2011). We hypothesized that depleted $\alpha$-tocopherol concentrations precede LDA and remain after LDA correction. Thus, the objective of this study was to determine serum $\alpha$-tocopherol concentrations of multiparous dairy cows with secondary LDA during the first month of lactation and without disease between -3 and 7 wk postpartum. 


\section{MATERIALS AND METHODS}

\section{Animals and Study Design}

All procedures involving animals were approved by the Oregon State University Institutional Animal Care and Use committee. The research was conducted on a 1,000-head commercial dairy farm in Oregon's Central Willamette Valley during spring and summer 2010. The cohort consisted of 161 multiparous Holstein cows (parity 2 to 7 ). Seven cows (2 or 3 parities) that were diagnosed with LDA (identified at d 6, 7, 13, 13, 17, 22, and 32 , respectively) and 10 control cows (not treated for diseases during the sampling period) similar in parity, calving month, and age were selected for this nested case-control study.

During the last 4 wk before expected calving, cows were housed in a straw-bedded freestall barn and were fed once in the morning (0730 h) a TMR based on corn, corn silage, and alfalfa and triticale hay, which met NRC guidelines (NRC, 2001) and contained supplemental vitamin E at $167 \mathrm{IU} / \mathrm{kg}$ of DM (Table 1). After calving, healthy cows stayed in the hospital pen for the first $2 \mathrm{~d}$, and then for $4 \mathrm{wk}$ in the early-lactation pen, and then, based on body size, in 3 mid-lactation pens. Cows diagnosed with LDA were moved back to the hospital pen for treatment. Cows from the hospital, early-lactation, and mid-lactation pens were fed at 0700, 0900, and $1000 \mathrm{~h}$, respectively, and at $1330 \mathrm{~h}$ for all cows, a TMR based on corn, corn silage, and alfalfa hay, that met NRC guidelines (NRC, 2001) and contained supplemental vitamin $\mathrm{E}$ at $24.5 \mathrm{IU} / \mathrm{kg}$ of DM (Table 1).

Starting $28 \mathrm{~d}$ before predicted calving date, the BCS of each cow was scored weekly until 4 wk postpartum and then at wk 7 and 14 postpartum (Edmonson et al., 1989). During the study period, cows were monitored daily for flakes in the milk, gait, appetite, general appearance, alertness, vaginal discharge, and retained placenta. Uterine discharge was checked twice a week, and urinary ketones and body temperature were checked if a cow appeared not healthy. Medical treatments were administered based on the standard operating procedures of the dairy farm, which, for LDA, was as follows: after LDA diagnosis by the herd manager, cows were moved to an isolation pen and the herd manager performed the "roll-and-toggle" procedure (Bartlett et al., 1995). After LDA correction, cows were moved to the hospital pen, received $0.5 \mathrm{~L}$ of dextrose i.v. $(50 \%$ dextrose; Aspen Veterinary Resources Ltd., Liberty, MO) and 2 capsules of the fiber, electrolyte, and vitamin A supplement Pecti-cap (Bio-Vet Inc., Blue Mounds, $\mathrm{WI}$ ), and were then injected i.m. with $20 \mathrm{~mL}$ of vitamin B complex (Aspen Veterinary Resources Ltd.). To prevent infections, cows were injected i.m. for up to 7 d with penicillin $(40 \mathrm{~mL} / \mathrm{d}$, Penicillin G Procaine; Aspen Veterinary Resources Ltd.), followed by treatment for up to $7 \mathrm{~d}$ with sulfadimethoxine $(30 \mathrm{~g} / \mathrm{d}$, Sulfasol soluble powder; Med-Pharmex, Pomona, CA).

\section{Blood Collection and Analysis}

Blood samples were taken at $\mathrm{d}-21(-24$ to -18$)$, $-14(-17$ to -11$),-7$ ( -10 to -5$),-3$ ( -4 or -3$),-1$ $(-2$ or -1$), 0,1,3,7,14,21,28,35,42$, and 49 postpartum within 10 min after morning feeding. Blood ( 5 to $8 \mathrm{~mL}$ ) was obtained from the coccygeal vein or artery in 10-mL serum Vacutainer tubes (BD Vacutainer Plus Plastic Serum Tubes, BD Diagnostics, Franklin Lakes, NJ), placed on ice, and transported to the laboratory, where serum was separated by centrifugation at room temperature for $20 \mathrm{~min}$ at $1,600 \times g$. Serum samples were stored at $-20^{\circ} \mathrm{C}$ until chemical analysis.

Serum $\alpha$-tocopherol concentrations were measured using a reversed-phase Phenomenex Synergi $4 \mu M$ Hydro-RP, $150 \times 4.6 \mathrm{~mm}$ column and a SecurityGuard cartridges AQ C18 pre-column, $3.0 \mathrm{~mm}$ i.d. (Phenomenex, Torrance, CA) with a LC-4B amperometric electrochemical detector (Bioanalytical Systems Inc., West Lafayette, IN), following Podda et al. (1996). An isocratic mobile phase of 99:1 (vol:vol) methanol:water containing $0.1 \%$ (wt:vol) lithium perchlorate was used with a run time of $9 \mathrm{~min}$ and the electrochemical detector set at $500 \mathrm{mV}$. After $100 \mu \mathrm{L}$ of serum was saponified in alcoholic $\mathrm{KOH}$ with $1 \%$ ascorbic acid, the sample was extracted with hexane and dried, and the residue was resuspended in ethanol:methanol (1:1). A $20-\mu \mathrm{L}$ aliquot of the extract was injected into the HPLC system. Serum concentrations of cholesterol (Stanbio Cholesterol LiquiColor Procedure No. 1010; Stanbio Laboratory, Boerne, TX), glucose (Stanbio Glucose Proc. No. 1075; Stanbio Laboratory), NEFA (ACS ACOD method, Wako Diagnostics, Richmond, VA), BHBA (Stanbio BHBA LiquiColor Proc. No. 2440; Stanbio Laboratory), urea N (Stanbio Urea Nitrogen Liqui-UV Proc. No. 2020; Stanbio Laboratory), haptoglobin (bovine-specific ELISA kit cat. no. 241070; Life Diagnostics Inc., West Chester, PA), serum amyloid A (SAA; multispecies ELISA kit cat. no. KAA0021; Life Technologies, Grand Island, NY), calcium (Stanbio Total Calcium LiquiColor Proc. No. 0150; Stanbio Laboratory), magnesium (Stanbio Magnesium LiquiColor Proc. No. 0130; Stanbio Laboratory), and phosphorus (Stanbio Phosphorus Liqui-UV Proc. No. 0830; Stanbio Laboratory) were measured according to manufacturer's instructions using a FLUOstar Omega microplate autoreader (BMG Labtech Inc., San Francisco, CA). 
Table 1. Feed and nutrient composition (\% diet DM, unless otherwise specified) of pre- and postpartum diets

\begin{tabular}{|c|c|c|}
\hline Item & Prepartum & Postpartum \\
\hline \multicolumn{3}{|l|}{ Feed composition } \\
\hline Grass silage & - & 2.13 \\
\hline Alfalfa hay $(20 \% \mathrm{CP}, 36 \% \mathrm{NDF})$ & 13.42 & 19.26 \\
\hline Corn silage & 27.77 & 20.93 \\
\hline Triticale hay (9\% CP, $60 \%$ NDF) & 13.69 & - \\
\hline Beet pulp & 3.41 & - \\
\hline Vitamin and mineral premix ${ }^{1}$ & 4.95 & - \\
\hline Vitamin and mineral premix ${ }^{2}$ & - & 2.96 \\
\hline $\mathrm{MagOx}^{3}$ & 0.18 & - \\
\hline Ground corn & 18.15 & - \\
\hline Corn (high-moisture ear corn) & - & 20.00 \\
\hline Corn distillers grain (incl. solubles) & 8.06 & 12.33 \\
\hline Canola meal & 6.69 & 6.40 \\
\hline Wheat distillers grain (incl. solubles) & - & 5.97 \\
\hline Bakery by-product & - & 6.39 \\
\hline EnerGII Regular ${ }^{4}$ & 1.82 & 1.74 \\
\hline Limestone (ground) & 1.85 & 0.94 \\
\hline Sodium bicarbonate & - & 0.94 \\
\hline \multicolumn{3}{|l|}{ Analyzed nutrient composition } \\
\hline $\mathrm{NE}_{\mathrm{L}}(\mathrm{Mcal} / \mathrm{kg}, \mathrm{DM}$ basis $)$ & 1.63 & 1.70 \\
\hline $\mathrm{CP}$ & 13.0 & 18.7 \\
\hline $\mathrm{ADF}$ & 27.1 & 16.9 \\
\hline $\mathrm{NDF}$ & 36.2 & 27.2 \\
\hline Calcium & 2.42 & 0.68 \\
\hline Phosphorus & 0.42 & 0.44 \\
\hline Magnesium & 0.46 & 0.32 \\
\hline Potassium & 1.30 & 1.23 \\
\hline Sodium & 0.072 & 0.243 \\
\hline Iron $(\mathrm{mg} / \mathrm{kg})$ & 469 & 570 \\
\hline Zinc $(\mathrm{mg} / \mathrm{kg})$ & 83 & 115 \\
\hline Copper $(\mathrm{mg} / \mathrm{kg})$ & 23 & 23 \\
\hline Manganese $(\mathrm{mg} / \mathrm{kg})$ & 65 & 91 \\
\hline Molybdenum (mg/kg) & 0.6 & 0.5 \\
\hline
\end{tabular}

${ }^{1}$ Provided to the diet DM: $6.7 \mathrm{~g} / \mathrm{kg}$ of $\mathrm{Ca}$ as calcium propionate, calcium carbonate, calcium chloride and mono-dicalcium phosphate, $1.4 \mathrm{~g} / \mathrm{kg}$ of $\mathrm{P}$ as mono-dicalcium phosphate, $8.0 \mathrm{~g} / \mathrm{kg}$ of $\mathrm{Cl}$ as ammonium and calcium chloride, $3.4 \mathrm{~g} / \mathrm{kg}$ of $\mathrm{Mg}$ as magnesium sulfate, $30 \mathrm{mg} / \mathrm{kg}$ of $\mathrm{K}, 0.99 \mathrm{~g} / \mathrm{kg}$ of S as magnesium, manganese, copper, cobalt, and zinc sulfate, $0.17 \mathrm{mg} / \mathrm{kg}$ of Co as cobalt sulfate, $15.2 \mathrm{mg} / \mathrm{kg}$ of $\mathrm{Cu}$ as copper sulfate, 1.012 $\mathrm{mg} / \mathrm{kg}$ of I as ethylenediaminedihydroiodide, $7.7 \mathrm{mg} / \mathrm{kg}$ of $\mathrm{Mn}$ as manganese sulfate, $0.31 \mathrm{mg} / \mathrm{kg}$ of Se as sodium selenite, $29.9 \mathrm{mg} / \mathrm{kg}$ of $\mathrm{Zn}$ as zinc sulfate, $10.8 \mathrm{kIU} / \mathrm{kg}$ of vitamin A, $4.6 \mathrm{kIU} / \mathrm{kg}$ of vitamin $\mathrm{D}_{3}, 167 \mathrm{IU} / \mathrm{kg}$ of vitamin $\mathrm{E}$ as all rac $\alpha$-tocopheryl acetate, $1.19 \mathrm{~g} / \mathrm{kg}$ of choline, $1.00 \mathrm{~g} / \mathrm{kg}$ of niacin, $26.8 \mathrm{mg} / \mathrm{kg}$ of monensin. ${ }^{2}$ Provided to the diet DM: $0.30 \mathrm{~g} / \mathrm{kg}$ of $\mathrm{Ca}, 0.23 \mathrm{~g} / \mathrm{kg}$ of P from ammonium polyphosphate, $0.20 \mathrm{~g} / \mathrm{kg}$ of $\mathrm{Mg}$, $1.23 \mathrm{~g} / \mathrm{kg}$ of $\mathrm{K}, 0.21 \mathrm{~g} / \mathrm{kg}$ of Na, $0.19 \mathrm{~g} / \mathrm{kg}$ of Cl, $0.26 \mathrm{~g} / \mathrm{kg}$ of S, $0.07 \mathrm{mg} / \mathrm{kg}$ of Co as cobalt sulfate, $0.05 \mathrm{mg} /$ $\mathrm{kg}$ of $\mathrm{Co}$ as organic cobalt, $12.4 \mathrm{mg} / \mathrm{kg}$ of $\mathrm{Cu}$ as copper sulfate, $4.42 \mathrm{mg} / \mathrm{kg}$ of $\mathrm{Cu}$ as organic copper, $1.76 \mathrm{mg} /$ $\mathrm{kg}$ of I as ethylenediaminedihydroiodide, $10.7 \mathrm{mg} / \mathrm{kg}$ of $\mathrm{Mn}$ as manganese sulfate, $0.81 \mathrm{mg} / \mathrm{kg}$ of $\mathrm{Mn}$ as organic manganese, $0.25 \mathrm{mg} / \mathrm{kg}$ of Se as sodium selenite, $59.0 \mathrm{mg} / \mathrm{kg}$ of $\mathrm{Zn}$ as zinc sulfate, $8.00 \mathrm{mg} / \mathrm{kg}$ of $\mathrm{Zn}$ as organic zinc, $5.01 \mathrm{kIU} / \mathrm{kg}$ of vitamin $\mathrm{A}, 1.23 \mathrm{kIU} / \mathrm{kg}$ of vitamin $\mathrm{D}_{3}, 24.5 \mathrm{IU} / \mathrm{kg}$ of vitamin $\mathrm{E}$ as all rac $\alpha$-tocopheryl acetate, $0.25 \mathrm{~g} / \mathrm{kg}$ of methionine.

${ }^{3}$ Guaranteed to contain no less than $56 \% \mathrm{Mg}$.

${ }^{4}$ Contained (DM basis) $90.4 \%$ total fat and $9.6 \% \mathrm{Ca}$ as calcium salts of long-chain FA (Inman, Clackamas, OR).

\section{Statistical Analysis}

Data were analyzed as repeated-measures-in-time ANOVA using the PROC MIXED procedure of SAS (version 9.2; SAS Institute, 2009). The molar ratio of $\alpha$-tocopherol to cholesterol was calculated to adjust for changes in lipid transport (Traber and Jialal, 2000) and stage of lactation (Weiss, 1998) To achieve a normal distribution for their serum concentrations, concentrations of glucose, NEFA, SAA, and $\alpha$-tocopherol to cholesterol molar ratio were ln-transformed, concentrations of haptoglobin and BHBA were twice ln-transformed, concentrations of cholesterol were square-root transformed, and concentrations of phosphorus $>11 \mathrm{mg} /$ $\mathrm{dL}$ (6 samples) were set at $11 \mathrm{mg} / \mathrm{dL}$. The variancecovariance structure of repeated measures within cow was modeled using the heterogeneous first-order autoregressive variance-covariance matrix. Fixed effects were LDA incidence (cases, control), parity $(2,>2)$, sampling time, and the interaction between LDA incidence and sampling time. To obtain the correct degrees of freedom, the KENWARDROGER option was invoked. 
To compare our results with previously published studies and identify early indicators of LDA, average serum concentrations in the last week before calving and the first $3 \mathrm{~d}$ postpartum were calculated using the trapezoidal rule and analyzed in PROC GLM, with LDA status and parity as fixed effects. In addition, we compared the results of the last blood sample before LDA diagnosis with those of control cows at $d 7$ postpartum in PROC GLM with LDA status and parity as fixed effects. Day 7 postpartum was chosen for comparison because most serum indicators reached their most extreme value at that time point. Potential cut-off values for detecting LDA in wk -1 or 1 postpartum were determined using Fisher's exact test. For wk 1 postpartum, we excluded samples taken at d 0,1 , or after LDA diagnosis. Values presented in the figures and tables are least squares means (LSM) and their standard errors (SEM) that are transformed back to their original measurement scale. All statistical tests were 2 -sided. Significance was declared at $P \leq 0.05$ and a tendency at 0.05 to 0.10 .

\section{RESULTS}

The incidence rate of LDA in this study cohort was $4.3 \%$ (7 of 161 cows). Cows with LDA were in either their second or third parity. Left displaced abomasum was corrected at postpartum d 6, 7, 13, 13, 17, 22, and 32, respectively, using the roll-and-toggle method, which did not have to be repeated for any cow. Each cow had morbidities before LDA diagnosis ( 5 cows had ketosis, 4 cows had metritis, 2 cows had milk fever, and 1 cow each retained placenta after twins, mastitis, or laminitis). Most cows had morbidities after LDA correction (until d 49 postpartum: 4 cows had ketosis, 1 cow had mastitis, and 1 cow died from an intestinal ulcer $2 \mathrm{~d}$ after LDA diagnosis at d 34 postpartum). The 10 control cows did not show signs of clinical diseases during the sampling period and had relatively normal serum concentrations of BHBA (range: 0.28 to 1.19 $\mathrm{m} M ;<1.2 \mathrm{~m} M$ as cut-off between healthy and subclinical ketosis; McArt et al., 2012), calcium (range: 6.9 to $11.8 \mathrm{mg} / \mathrm{dL} ;>6 \mathrm{mg} / \mathrm{dL}$ as cut-off between clinical milk fever and subclinical milk fever or inflammation-associated hypocalcemia; Goff, 2008; Reinhardt et al., 2011), and magnesium (range: 1.33 to $3.38 \mathrm{mg} / \mathrm{dL} ;>1.15 \mathrm{mg} /$ $\mathrm{dL}$ as cut-off between hypomagnesemia and subclinical tetany; Goff, 2008). Before calving, all 17 cows were visually healthy.

\section{Serum Vitamin E, Cholesterol, BCS, and LDA}

Cows that developed LDA during the first month postpartum had, on average, lower serum $\alpha$-tocopherol concentrations $(P=0.003 ;$ Figure $1 \mathrm{~A})$ and $\alpha$-tocopherol to cholesterol molar ratios $(P=0.03$; results not shown $)$ compared with healthy cows. Sampling time affected serum $\alpha$-tocopherol concentrations and $\alpha$-tocopherol to cholesterol molar ratios (both $P<0.0001$ ), with concentrations decreasing dramatically in the first week postpartum in all cows (Figure 1A). The nadir $\alpha$-tocopherol concentrations at $\mathrm{d} 7$ postpartum were lower in cases than controls $(5.1 \pm 1.0 \mu M$ vs. $9.2 \pm 0.8$ $\mu M ; P=0.004)$. In control cows, $\alpha$-tocopherol concentrations returned to prepartal concentrations $(\sim 15 \mu M)$ by $28 \mathrm{~d}$ postpartum. Serum $\alpha$-tocopherol remained lower in cases compared with controls ( $<10 \mu M$ vs. 15 $\mu M$ ) during the entire postpartal sampling period (all $P<0.03 ;$ Figure 1A).

Serum cholesterol changed differently over time in control and case cows $\left(P_{\text {Interaction }}=0.001\right.$; Figure 1B). Cholesterol concentrations were similar in the 2 groups until d 3 postpartum, but were lower in LDA cows for the remaining sampling period (all $P<0.05$; Figure 1B). A tendency to a significant interaction between LDA incidence and sampling time was observed for BCS $(P=0.09)$, which were only lower for LDA cows at 7 and 14 wk postpartum (Figure 1C).

\section{Energy, Inflammation Status, and LDA}

Cases had on average greater NEFA concentrations than control cows $(P<0.0001)$, whereas serum BHBA changed differently over time in control and case cows $\left(P_{\text {Interaction }}=0.04 ;\right.$ Figure $\left.2 \mathrm{~B}\right)$. Only during the first 4 wk postpartum did cases have greater BHBA concentrations than control cows (Figure 2B). Sampling time affected serum NEFA and BHBA (both $P<0.0001$ ). Elevated NEFA and BHBA concentrations were observed during the first weeks postpartum in all cows; however, they started earlier and persisted longer for NEFA in cases (Figures 2A, B).

Control and LDA cows changed differently over time for serum haptoglobin $\left(P_{\text {Interaction }}=0.003\right)$ and SAA $\left(P_{\text {Interaction }}=0.10\right)$, respectively (Figures $\left.2 \mathrm{C}, \mathrm{D}\right)$. Elevated haptoglobin and SAA concentrations were observed during d 1 postpartum in all cows; however, they were greater and remained elevated for a longer period in LDA compared with control cows (Figures 2C, D). Fold changes between cases and controls were greater and more persistent for serum haptoglobin than for SAA (Figures 2C, D).

\section{Macronutrient Status and LDA}

Cows with LDA had, on average, lower phosphorus concentrations than control cows $(P<0.0001$; Figure $3 \mathrm{~A})$. The LDA effect, however, was significant for only 
A)

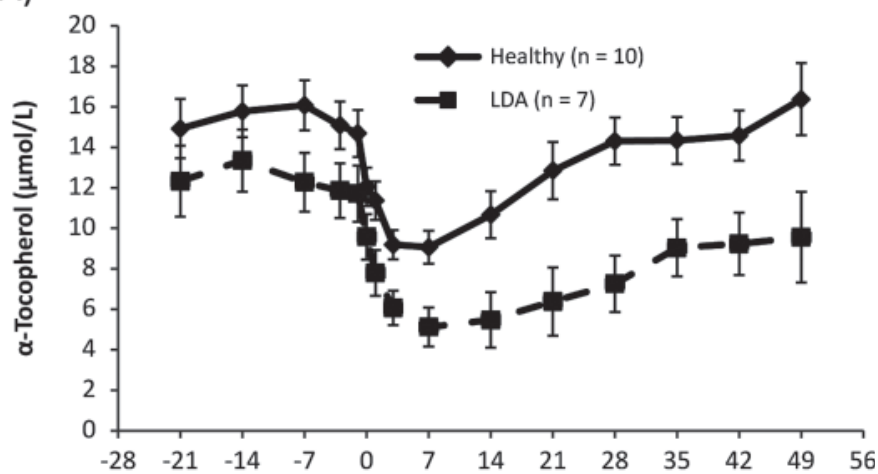

B)

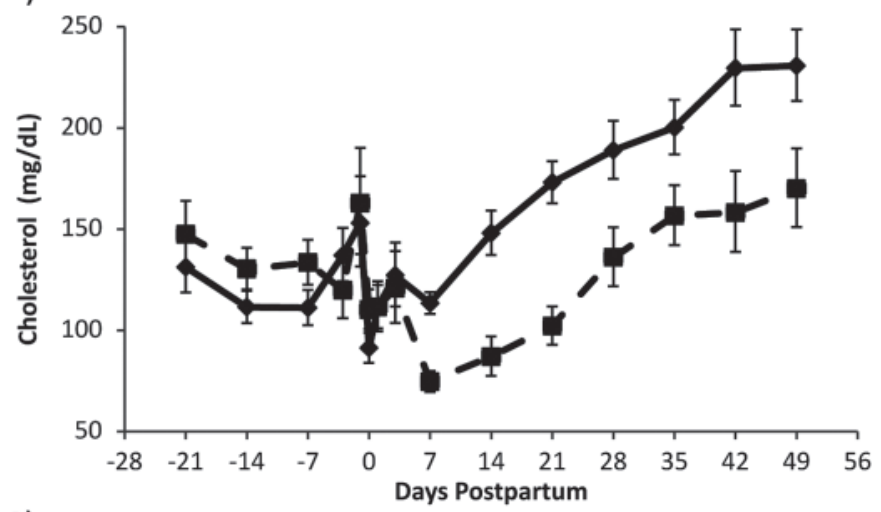

C)

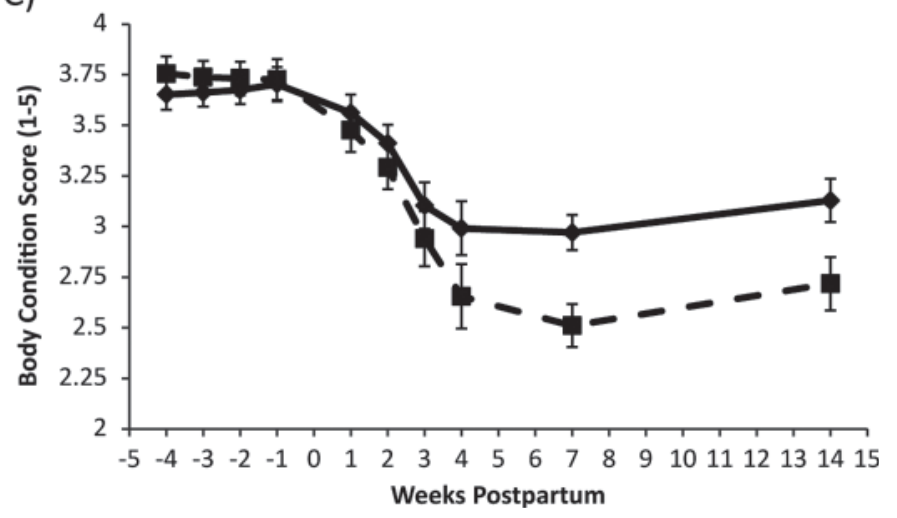

Figure 1. Serum concentrations ( $\mathrm{LSM} \pm \mathrm{SEM}$ ) of $(\mathrm{A}) \alpha$-tocopherol, and (B) cholesterol between $\mathrm{d}-21$ and 49 postpartum, and (C) BCS between wk -4 and 14 postpartum in healthy cows and cows with left displaced abomasum (LDA) between d 6 and 32 postpartum.

a few sampling times $(\mathrm{d}-21,-3,0,35$, and 49 postpartum; Figure 3A). A tendency to a significant interaction between LDA incidence and sampling time was observed for serum urea $\mathrm{N}(P=0.09)$, as LDA cows had lower urea $\mathrm{N}$ concentrations starting d 7 postpartum (Figure $3 \mathrm{~B}$ ).

In contrast, a temporary decrease in serum concentrations of calcium, magnesium, and glucose was observed in cows that developed LDA (Figure 4). Cases had lower serum calcium concentrations $(P=0.002$;
Figure 4A) and magnesium concentrations $(P=0.04$; Figure 4B) on average than healthy cows. The LDA effect, however, was significant only at d 14 postpartum for phosphorus (Figure 4A) and at d 7, 21, and 28 postpartum for magnesium (Figure 4B). No significant overall effects were observed for serum glucose concentrations; glucose concentrations were, however, greater at d 0 and lower at d 28 postpartum in cases compared with controls (Figure 4C).

\section{Early Serum Indicator of LDA}

To identify early indicators of LDA, we compared the average serum concentrations of LDA cases and controls before LDA diagnosis (Table 2). Differences in $\alpha$-tocopherol concentrations and $\alpha$-tocopherol to cholesterol molar ratio were apparent before calving and became greater as LDA diagnosis approached (Table 2). Cows that subsequently developed LDA had $24 \%$ lower serum $\alpha$-tocopherol concentrations during the last week prepartum, $33 \%$ lower concentrations during the first 3 d postpartum, and $45 \%$ lower concentrations at the last blood sampling before LDA diagnosis compared with healthy cows. A similar trend was observed for $\alpha$-tocopherol to cholesterol ratios (Table 2). Cows that subsequently developed LDA had prepartum greater NEFA and phosphorus concentrations than healthy cows (Table 2). After calving, BHBA, haptoglobin, and SAA concentrations were higher in cases than in control cows with the differences becoming greater as LDA diagnosis approached (Table 2).

Potential cut-off values for early serum indicators of LDA were evaluated and yielded no significant cut-off values for wk -1 prepartum. In contrast, significant cut-off values for serum concentrations of $\alpha$-tocopherol $(7 \mu M)$, BHBA (1 mM; 1 LDA cow misclassified; $P<$ $0.001)$, haptoglobin $(200 \mathrm{mg} / \mathrm{L} ; 1$ LDA cow misclassified; $P<0.001)$, and SAA $(100 \mathrm{mg} / \mathrm{L} ; 1 \mathrm{LDA}$ cow and 1 control cow misclassified; $P<0.001$ ) were observed for d 3 or 7 postpartum (excluding samples taken after LDA diagnosis). Six out of 7 case cows had $\alpha$-tocopherol concentrations below $7 \mu M$, whereas 3 out of 10 control cows had $\alpha$-tocopherol concentrations below $7 \mu M$ during this period $(P=0.05)$; the only case cow above 7 $\mu M$ decreased below $7 \mu M 8 \mathrm{~d}$ before LDA diagnosis.

\section{DISCUSSION}

Our study demonstrates that serum $\alpha$-tocopherol concentrations may be a useful diagnostic parameter for LDA because group differences in $\alpha$-tocopherol concentrations and $\alpha$-tocopherol to cholesterol molar ratio began prepartum and became more pronounced as LDA diagnosis approached. Second, our results indicate 

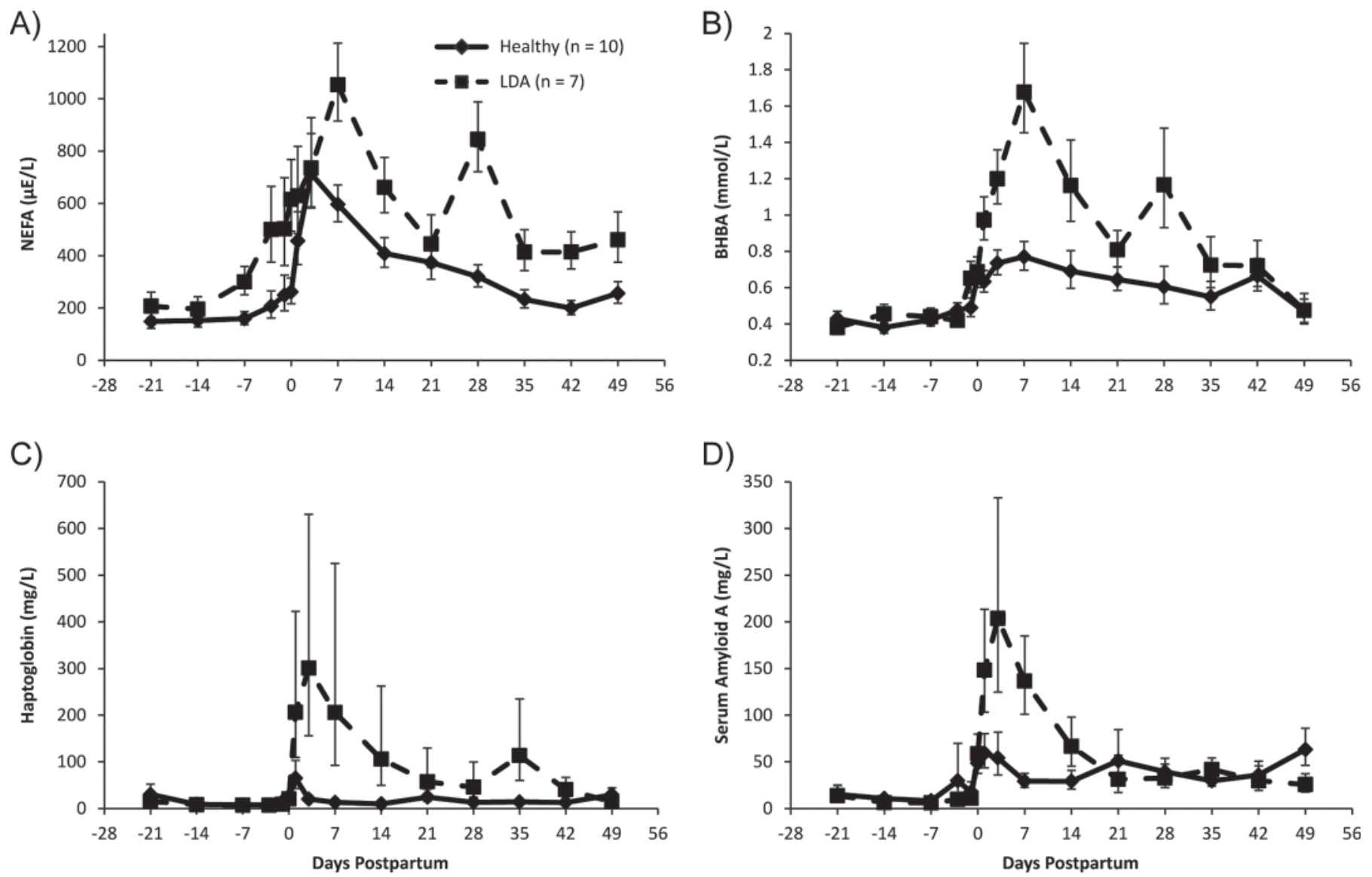

Figure 2. Serum concentrations (LSM \pm SEM) of (A) NEFA, (B) BHBA, (C) haptoglobin, and (D) serum amyloid A between d -21 and 49 postpartum in healthy cows and cows with left displaced abomasum (LDA) between d 6 and 32 postpartum.

that negative energy balance, inflammation, and lower vitamin E concentrations may precede LDA. Third, our study indicates that cows remain in a lower nutrient status for weeks after LDA correction.

Serum $\alpha$-tocopherol concentrations in healthy cows followed similar trends, as has been previously described (Meglia et al., 2006; Weiss et al., 2009), significantly decreasing in the first week after calving and then increasing within a few week back to prepartum concentrations (Figure 1A). Herdt and Smith (1996) reported that lactation stage accounted for $47 \%$ of the overall variability in serum $\alpha$-tocopherol concentrations. Dietary fat and $\alpha$-tocopherol increased $\alpha$-tocopherol concentrations in blood (Weiss et al., 1994; Weiss and Wyatt, 2003). Literature about the association between DMI and $\alpha$-tocopherol concentrations in blood is limited. Goff et al. (2002) reported that mastectomized cows had greater plasma $\alpha$-tocopherol concentrations than intact cows in the last 2 wk prepartum, although DMI did not differ between groups. Furthermore, the depleted $\alpha$-tocopherol concentrations of mastectomized cows early postpartum, when their DMI was similar or greater than before calving, suggested that lower feed intake alone could not explain the decrease in $\alpha$-tocopherol concentrations after parturition. A decrease in $\alpha$-tocopherol concentrations during the first week postpartum even occurs after vitamin E supplementation (Meglia et al., 2006; Weiss et al., 2009) and is thought to result from a combination of increased lipid peroxidation and production of reactive oxygen species, increased secretion of $\alpha$-tocopherol into colostrum and milk, depressed feed intake, inflammation, and decreased lipid absorption and transport (Baldi, 2005). Serum $\alpha$-tocopherol concentrations in this study were on the higher end of what have been previously reported (LeBlanc et al., 2004; Weiss et al., 2009; Bouwstra et al., 2010).

Cholesterol concentrations in our study (Figure 1B) were similar to those reported previously (Herdt and Smith, 1996; Guzelbektes et al., 2010; Stengärde et al., 2010). Blood cholesterol, which is primarily in the high density lipoprotein fraction, is considered an indicator of lipoprotein concentrations and decreased with $\alpha$-tocopherol around calving (Herdt and Smith, 
A)

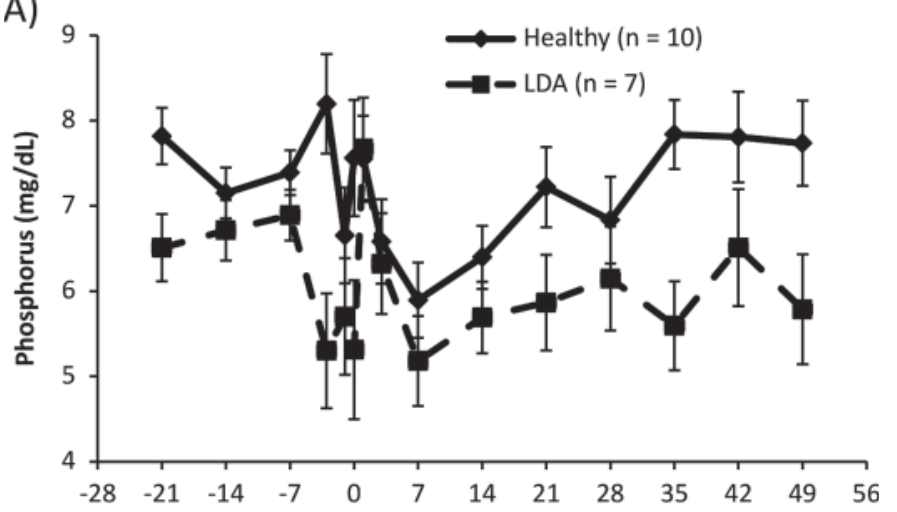

B)

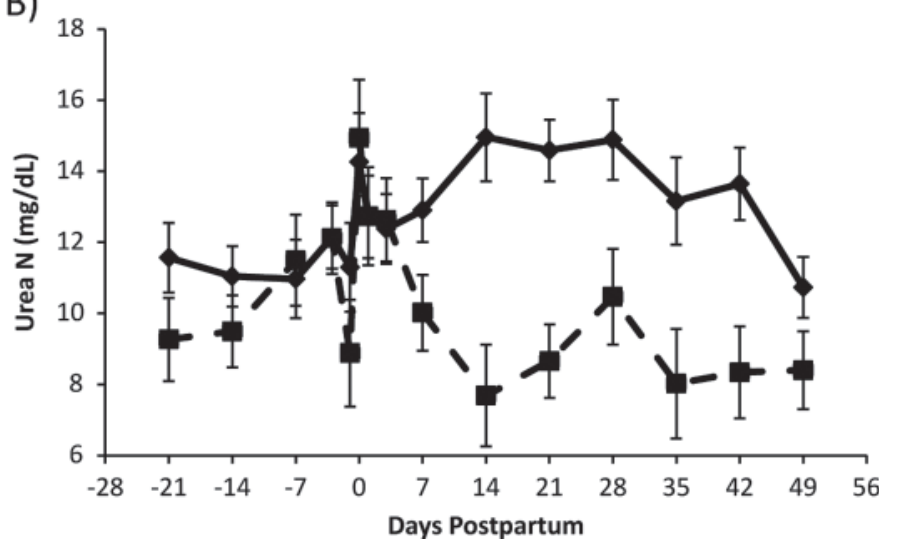

Figure 3. Serum concentrations (LSM \pm SEM) of (A) phosphorus and (B) urea $\mathrm{N}$ between $\mathrm{d}-21$ and 49 postpartum in healthy cows and cows with left displaced abomasum (LDA) between d 6 and 32 postpartum.

1996). Fat feeding and feed restriction increase cholesterol concentrations for increased lipid transport (Weiss and Wyatt, 2003; Bjerre-Harpøth et al., 2012), whereas heat and inflammation-associated diseases, in particular liver disorders, decrease cholesterol by impairing lipid transport (Bobe et al., 2004; Abeni et al., 2007; Vogel et al., 2011). Because serum lipoproteins transport $\alpha$-tocopherol in blood (Traber and Jialal, 2000), $\alpha$-tocopherol is usually divided by cholesterol concentration to adjust for changes in lipid transport (Herdt and Smith, 1996).

Cows that subsequently developed LDA had $45 \%$ lower serum $\alpha$-tocopherol concentrations and 39\% lower $\alpha$-tocopherol to cholesterol molar ratios than healthy cows at the last blood sampling before LDA diagnosis (Table 2). This study is, to our knowledge, the first report of serum $\alpha$-tocopherol concentrations before LDA. Similar differences in $\alpha$-tocopherol concentrations have been reported for cows after LDA diagnosis (Mudron et al., 1997; Hasanpour et al., 2011) and in cows with severe fatty liver (Hidiroglou and Hartin, 1982). In contrast,

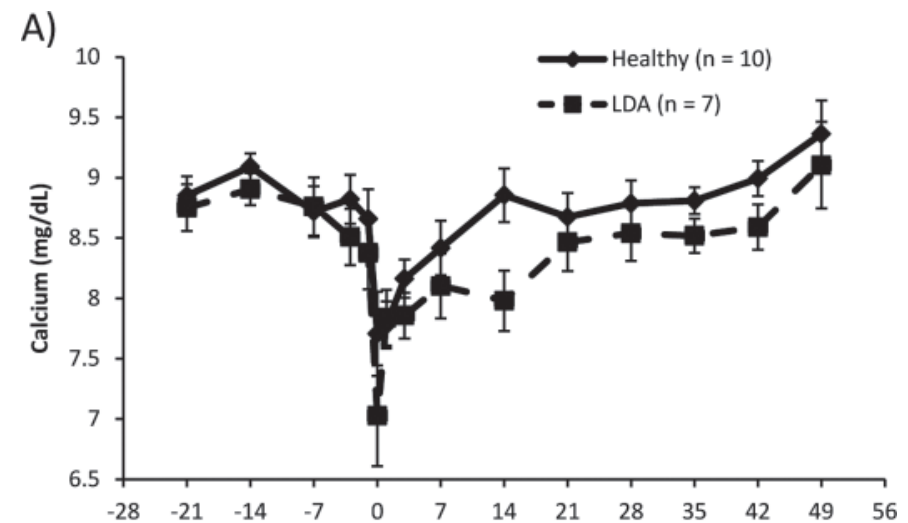

B)
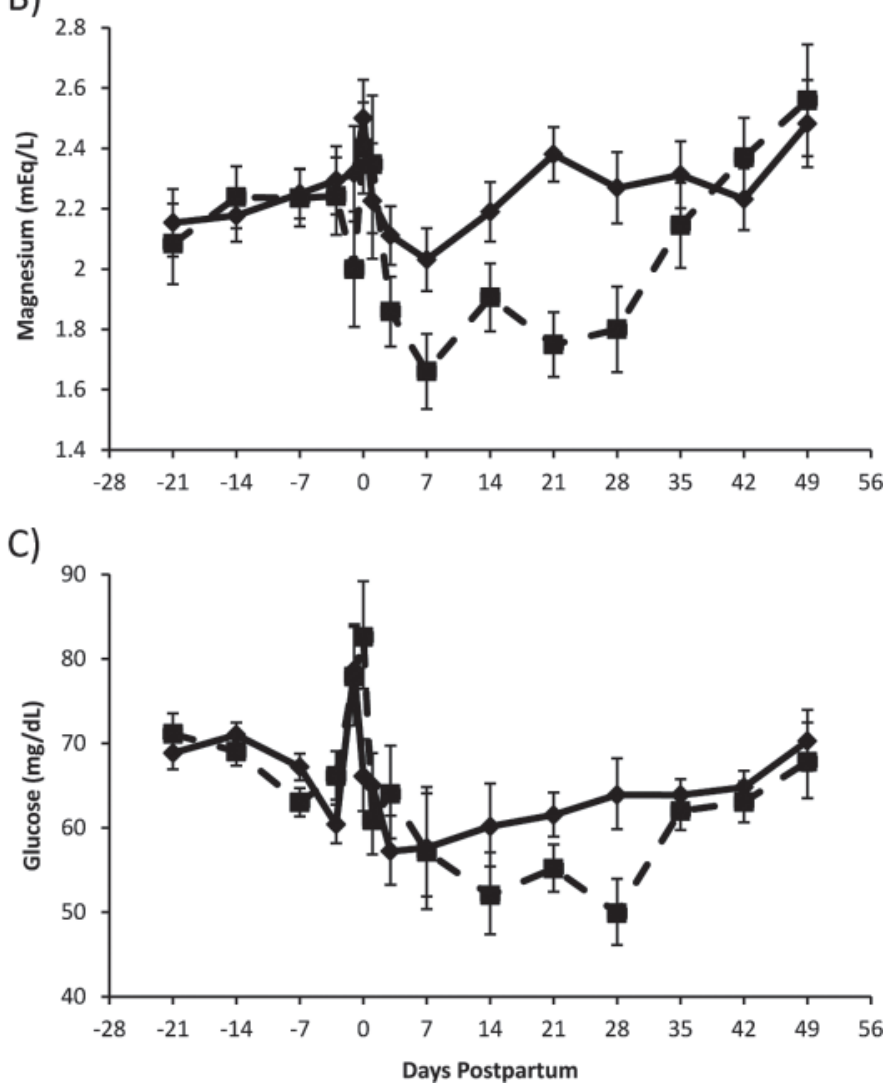

Figure 4. Serum concentrations (LSM \pm SEM) of (A) calcium, (B) magnesium, and (C) glucose between $\mathrm{d}-21$ and 49 postpartum in healthy cows and cows with left displaced abomasum (LDA) between d 6 and 32 postpartum.

ketosis, mastitis, laminitis, and metritis are associated with nonsignificant or smaller changes $(<20 \%$ lower $)$ in $\alpha$-tocopherol concentrations (Erskine et al., 1987; LeBlanc et al., 2004; Sivertsen et al., 2005) and, thus, cannot explain the large differences between LDA and control cows in serum $\alpha$-tocopherol and $\alpha$-tocopherol to cholesterol molar ratio before LDA diagnosis (Table 2). A lower DMI might be a probable causative factor for 


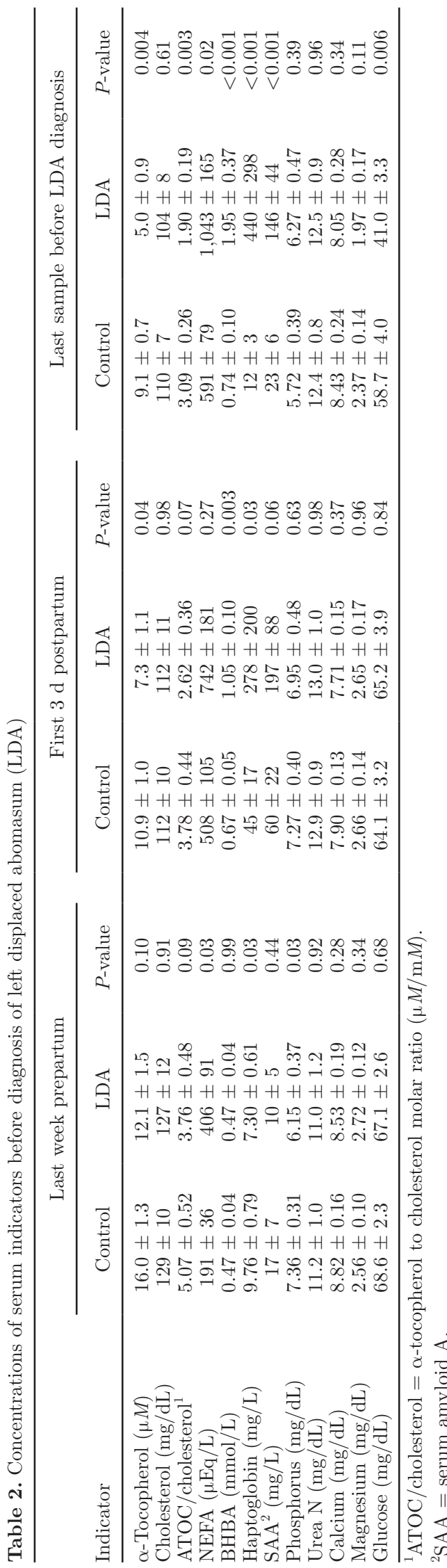

the lower serum $\alpha$-tocopherol concentrations in LDA cows, but in the absence of DMI data in our study we cannot determine whether lower $\alpha$-tocopherol concentrations in LDA cows were independent of feed intake. This should be addressed in future studies. Goff et al. (2002) suggested, based on their results in mastectomized cows, that factors other than feed intake, such as increased oxidation, play a role in lower $\alpha$-tocopherol in blood around calving.

A potential early indicator of LDA is serum $\alpha$-tocopherol concentration, with a potential cut-off value of $7 \mu M$. All cows that subsequently developed LDA had serum $\alpha$-tocopherol concentrations $<7 \mu M$, whereas only 3 out of 10 control cows had $\alpha$-tocopherol concentrations $<7 \mu M$ during the study. Weiss et al. (1997) reported that cows with plasma $\alpha$-tocopherol concentrations $<3 \mu \mathrm{g} / \mathrm{mL}$ (equivalent to $7 \mu M$ ) are 9.4 times more likely to have clinical mastitis than cows with greater $\alpha$-tocopherol concentrations, and NRC dietary guidelines (NRC, 2001) and Weiss (1998) suggest $3 \mu \mathrm{g} / \mathrm{mL}$ as a target for health and immune function. In contrast, Politis et al. (2012) reported that cows with serum $\alpha$-tocopherol concentrations $<2 \mu \mathrm{g} / \mathrm{mL}$ at calving were 4 times more likely to have clinical mastitis than cows with $\alpha$-tocopherol concentrations of $\geq 2$ to 3 $\mu \mathrm{g} / \mathrm{mL}$. In addition to Politis et al. (2012), many other studies have reported healthy cows with $\alpha$-tocopherol concentrations $<3$ or even $<2 \mu \mathrm{g} / \mathrm{mL}$ (Mudron et al., 1997; Goff et al., 2002; Weiss et al., 2009). Given the small number of LDA cows in one herd in the present study, large, multi-herd field studies are needed to confirm serum $\alpha$-tocopherol concentration as a potential early indicator of LDA and to determine the potential cut-off value for serum $\alpha$-tocopherol.

To date, NEFA concentrations $>300$ to $500 \mu \mathrm{Eq} / \mathrm{L}$ in the last week prepartum and BHBA concentrations $>1.0$ to $1.4 \mathrm{~m} M$ during the first week postpartum have been confirmed as early indicators of LDA in large, multi-herd field trials (LeBlanc et al., 2005; Ospina et al., 2010; Chapinal et al., 2011), establishing negative energy balance as an early risk factor for LDA. This contention is further supported by the lower serum phosphate concentrations we observed in cows that subsequently developed LDA (Table 2). Low serum phosphate concentrations have been reported in cows after LDA diagnosis (Grünberg et al., 2005; Kalaitzakis et al., 2010). In contrast, the evidence for calcium concentration as an early indicator is inconsistent (LeBlanc et al., 2005; Chapinal et al., 2011). We observed similar patterns in serum concentrations of NEFA, BHBA, and calcium in this study. Serum $\alpha$-tocopherol concentration is potentially a better indicator than NEFA or BHBA concentration because significant group differences for $\alpha$-tocopherol were detected before calving and 
became more pronounced as LDA diagnosis approached (Table 2). In contrast, elevated BHBA concentrations usually begin after calving, whereas many healthy cows have elevated NEFA concentrations in the first week postpartum (LeBlanc et al., 2005).

Another potential early indicator of LDA is elevated postpartal serum haptoglobin concentrations with a potential cut-off value of $200 \mathrm{mg} / \mathrm{L}$ at d 3 or 7 postpartum. Elevated postpartal haptoglobin concentrations have been reported as early indicator of metritis (Huzzey et al., 2009). In our study, both inflammation markers (haptoglobin and SAA) were increased postpartum before LDA diagnosis, suggesting inflammation as a potential risk factor for LDA. Both inflammation markers had greater postpartal fold-changes between cases and controls than did markers of negative energy status before LDA diagnosis (Table 2). Results from a large, multi-herd study by Humblet et al. (2006) suggested elevated haptoglobin concentration as a more specific disease indicator and elevated SAA as a more sensitive disease indicator in dairy cows. Our study is, to our knowledge, the first report of serum concentrations of haptoglobin and SAA before LDA. Previous studies reported 4.5- and 1.94-fold greater haptoglobin concentrations and 4.6-fold greater SAA concentrations in cows after LDA diagnosis compared with control cows (Guzelbektes et al., 2010; Stengärde et al., 2010).

After LDA correction, indicators of energy and nutrient status (NEFA, phosphorus, and urea N) and serum $\alpha$-tocopherol concentrations remained lower in cases than in healthy cows up to d 49. Cases had also lower BCS in wk 7 and 14 postpartum than control cows, suggesting that their lower nutrient status may persist beyond d 49. Similarly, Østergaard and Gröhn (1999) reported lower BW (>30 kg) for more than 6 wk after LDA diagnosis. Unfortunately, we did not measure feed intake in this study and, thus, cannot determine whether the persistent lower nutrient status is a consequence of lower DMI, lower nutrient absorption, or a combination of both. The persistent lower energy and nutrient status in LDA cows may explain the delayed reproductive performance and increased mortality and culling rates in cows that had LDA (Raizman and Santos, 2002). Future studies are warranted to examine why energy and nutrient status remain lower in cows that had LDA.

A strength of the current study was the intensive blood sampling schedule over $10 \mathrm{wk}$ ( -3 to $7 \mathrm{wk}$ postpartum), which allowed us to demonstrate that lower $\alpha$-tocopherol concentrations preceded and remained after LDA correction. The fact that our results for previously examined indicators of LDA are consistent with the literature suggests that our findings, despite the small size of the study and the lack of cows with primary LDA, are generalizable. This is a retrospective case-control study and, thus, can only establish associations between serum vitamin E concentrations and LDA. Vitamin E alimentation trials are required to determine causality. Previous vitamin E intervention trials showed a nonsignificant decrease in LDA cases in one (primiparous cows: 1 of 62 in treatment group vs. 6 of 75 in control group; multiparous cows: 14 of 142 in treatment vs. 18 of 141 in control; Erskine et al., 1997) but not in another large field study (28 of 571 in treatment vs. 26 of 571 in control; LeBlanc et al., 2002). Dosage (4,470 IU of vitamin $\mathrm{E}$ as $\mathrm{D}$ - $\alpha$-tocopherol in Erskine et al., 1997, vs. 3,000 IU of vitamin E as $R R R$ $\alpha$-tocopheryl acetate in LeBlanc et al., 2002), baseline prepartal $\alpha$-tocopherol concentrations (7.2 vs. $6.3 \mu M$ ), pre- and postpartum diets (not specified in both studies), and alimentation route (i.m. vs. s.c. injection) and timing ( 2 vs. 1 wk prepartum) may determine the outcome of vitamin $\mathrm{E}$ alimentation trials. It should be noted that lower serum $\alpha$-tocopherol concentrations may be a biomarker of disease, low feed intake, or both, and vitamin E supplementation may not reverse the occurrence of LDA.

\section{CONCLUSIONS}

Serum concentrations of $\alpha$-tocopherol and indicators of energy and nutrient status and inflammation were measured from -3 to $7 \mathrm{wk}$ postpartum in dairy cows that developed LDA in the first month of lactation and were compared with those concentrations in healthy cows. Negative energy balance, inflammation, and lower vitamin E concentrations all preceded LDA onset and, thus, might be potential early indicators for developing LDA. Cases remained in lower nutrient status, including vitamin $\mathrm{E}$, for at least 4 wk after LDA correction. This study was small with a limited number of LDA cows in a single commercial herd; larger studies under well-controlled conditions are warranted to examine the role of vitamin $\mathrm{E}$ in LDA.

\section{ACKNOWLEDGMENTS}

This study was financially supported by the Linus Pauling Institute, Oregon State University (Corvallis), the Oregon State University Agricultural Research Foundation, the Oregon Beef Council, the Eckelman graduate student scholarship, and a grant from Diamond V (Cedar Rapids, IA). The authors acknowledge the owners and staff of VanBeek Dairy for use of their animals; S. Bledsoe, B. Block, B. Bronson, A. Fadden, M. Keller, M. McGuire, P. Ramsing, A. Rudolph, D. Sabedra, C. Sause, C. Shriver-Munsch, M. Swearingen, and E. Zaworski for their assistance with sample col- 
lection and data entry (all in Department of Animal Sciences, Oregon State University, Corvallis); and S. W. Leonard for technical assistance with vitamin E analysis (Linus Pauling Institute, Oregon State University, Corvallis).

\section{REFERENCES}

Abeni, F., L. Calamari, and L. Stefanini. 2007. Metabolic conditions of lactating Friesian cows during the hot season in the Po valley. 1. Blood indicators of heat stress. Int. J. Biometeorol. 52:87-96.

Baldi, A. 2005. Vitamin E in dairy cows. Livest. Prod. Sci. 98:117122 .

Bartlett, P. C., M. Kopcha, P. H. Coe, N. K. Ames, P. L. Ruegg, and R. J. Erskine. 1995. Economic comparison of the pyloro-omentopexy vs the roll-and-toggle procedure for treatment of left displacement of the abomasums in dairy cattle. J. Am. Vet Med. Assoc. 206:1156-1162.

Bjerre-Harpøth, V., N. C. Friggens, V. M. Thorup, T. Larsen, B. M. Damgaard, and K. L. Ingvartsen. 2012. Metabolic and production profiles of dairy cows in response to decreased nutrient density to increase physiological imbalance at different stages of lactation. J. Dairy Sci. 95:2362-2380.

Bobe, G., J. W. Young, and D. C. Beitz. 2004. Invited review: Pathology, etiology, prevention, and treatment of fatty liver in dairy cows. J. Dairy Sci. 87:3105-3124.

Bouwstra, R. J., M. Nielen, J. A. Stegeman, P. Dobbelaar, J. R. Newbold, E. H. J. M. Jansen, and T. van Werven. 2010. Vitamin E supplementation during the dry period in dairy cattle. Part I: Adverse effect on incidence of mastitis postpartum in a double-blind randomized field trial. J. Dairy Sci. 93:5684-5695.

Castillo, C., J. Hernández, I. Valverde, V. Pereira, J. Sotillo, M. López Alonso, and J. L. Benedito. 2006. Plasma malonaldehyde (MDA) and total antioxidant status (TAS) during lactation in dairy cows. Res. Vet. Sci. 80:133-139.

Chapinal, N., M. Carson, T. F. Duffield, M. Capel, S. Godden, M. Overton, J. E. P. Santos, and S. J. LeBlanc. 2011. The association of serum metabolites with clinical disease during the transition period. J. Dairy Sci. 94:4897-4903.

Doll, K., M. Sickinger, and T. Seeger. 2009. New aspects in the pathogenesis of abomasal displacement. Vet. J. 181:90-96.

Edmonson, A. J., I. J. Lean, L. D. Weaver, T. Farver, and G. Webster. 1989. A body condition scoring chart for Holstein dairy cows. J. Dairy Sci. 72:68-78.

Erskine, R. J., P. C. Bartlett, T. Herdt, and P. Gaston. 1997. Effects of parenteral administrations of vitamin $\mathrm{E}$ on health of periparturient dairy cows. J. Am. Vet. Med. Assoc. 211:466-469.

Erskine, R. J., R. J. Eberhart, L. J. Hutchinson, and R. W. Scholz. 1987. Blood selenium and glutathione peroxidase activities in dairy herds with high and low somatic cell counts. J. Am. Vet. Med. Assoc. 190:1417-1421.

Geishauser, T. 1995. Abomasal displacement in the bovine-A review on the character, occurrence, aetiology and pathogenesis. Zentralbl. Veterinarmed. A 42:229-251.

Goff, J. P. 2008. The monitoring, prevention, and treatment of milk fever and subclinical hypocalcemia in dairy cows. Vet. J. 176:50-57.

Goff, J. P., K. Kimura, and R. L. Horst. 2002. Effect of mastectomy on milk fever, energy, and vitamins A, E, and $\beta$-carotene. J. Dairy Sci. 85:1427-1436.

Grünberg, W., P. Constable, U. Schröder, R. Staufenbiel, D. Morin, and M. Rohn. 2005. Phosphorus homeostasis in dairy cows with abomasal displacement or abomasal volvulus. J. Vet. Intern. Med. 19:894-898

Guzelbektes, H., I. Sen, M. On, P. D. Constable, M. Boydak, and A. Coskun. 2010. Serum amyloid A and haptoglobin concentrations and liver fat percentage in lactating dairy cows with abomasal displacement. J. Vet. Intern. Med. 24:213-219.
Hasanpour, A., N. Saranjam, and B. Amuoghli Tabrizi. 2011. Antioxidant concentration status in the serum of cows with left displacement abomasum. Global Vet. 7:478-481.

Herdt, T. H., and J. C. Smith. 1996. Blood-lipid and lactation stage factors affecting serum vitamin E concentrations and vitamin $\mathrm{E}$ cholesterol ratios in dairy cattle. J. Vet. Diagn. Invest. 8:228-232.

Hidiroglou, M., and K. E. Hartin. 1982. Vitamins A, E and selenium blood levels in fat cow syndrome. Can. Vet. J. 23:255-258.

Humblet, M. F., H. Guyot, B. Boudry, F. Mbayahi, C. Hanzen, F. Rollin, and J. M. Godeau. 2006. Relationship between haptoglobin, serum amyloid A, and clinical status in a survey of dairy herds during a 6-month period. Vet. Clin. Pathol. 35:188-193.

Huzzey, J. M., T. F. Duffield, S. J. LeBlanc, D. M. Veira, D. M. Weary, and M. A. G. von Keyserlingk. 2009. Short communication: Haptoglobin as an early indicator of metritis. J. Dairy Sci. 92:621-625.

Kalaitzakis, E., N. Panousis, N. Roubies, E. Kaldrymidou, and H. Karatzias. 2010. Macromineral status of dairy cows with concurrent left abomasal displacement and fatty liver. N. Z. Vet. J. $58: 307-311$.

LeBlanc, S. J., T. F. Duffield, K. E. Leslie, K. G. Bateman, J. TenHag, J. S. Walton, and W. H. Johnson. 2002. The effect of prepartum injection of vitamin $\mathrm{E}$ on health in transition dairy cows. J. Dairy Sci. 85:1416-1426.

LeBlanc, S. J., T. H. Herdt, W. M. Seymour, T. F. Duffield, and K. E. Leslie. 2004. Prepartum serum vitamin E, retinol, and betacarotene in dairy cattle, and their association with disease. J. Dairy Sci. 87:609-619.

LeBlanc, S. J., K. E. Leslie, and T. F. Duffield. 2005. Metabolic predictors of displaced abomasum in dairy cattle. J. Dairy Sci. $88: 159-170$.

McArt, J. A. A., D. V. Nydam, and G. R. Oetzel. 2012. Epidemiology of subclinical ketosis in early lactation dairy cows. J. Dairy Sci. 95:5056-5066.

Meglia, G. E., S. K. Jensen, C. Lauridsen, and K. Persson Waller. 2006. $\alpha$-Tocopherol concentration and stereoisomer composition in plasma and milk from dairy cows fed natural or synthetic vitamin E around calving. J. Dairy Res. 73:227-234.

Mudron, P., J. Rehage, H. P. Sallman, M. Mertens, H. Scholz, and G. Kovac. 1997. Plasma and liver $\alpha$-tocopherol in dairy cows with left abomasal displacement and fatty liver. Zentralbl. Veterinarmed. A $44: 91-97$.

NRC. 2001. Nutrient Requirements of Dairy Cattle. 7th rev. ed. National Acad. Sci., Washington, DC

Ospina, P. A., D. V. Nydam, T. Stokol, and T. R. Overton. 2010. Evaluation of nonesterified fatty acids and $\beta$-hydroxybutyrate in transition dairy cattle in the northeastern United States: Critical thresholds for prediction of clinical diseases. J. Dairy Sci. 93:546-554.

Østergaard, S., and Y. T. Gröhn. 1999. Effect of diseases on test day milk yield and body weight of dairy cows from Danish research herds. J. Dairy Sci. 82:1181-1201.

Podda, M., C. Weber, M. G. Traber, and L. Packer. 1996. Simultaneous determination of tissue tocopherols, tocotrienols, ubiquinols, and ubiquinones. J. Lipid Res. 37:893-901.

Politis, I. 2012. Reevaluation of vitamin E supplementation of dairy cows: Bioavailability, animal health and milk quality. Animal 6:1427-1434.

Politis, I., G. Theodorou, A. D. Lampidonis, A. Kominakis, and A. Baldi. 2012. Short communication: Oxidative status and incidence of mastitis relative to blood $\alpha$-tocopherol concentrations in the postpartum period in dairy cows. J. Dairy Sci. 95:7331-7335.

Raizman, E. A., and J. E. P. Santos. 2002. The effect of left displacement of abomasum corrected by toggle-pin suture on lactation, reproduction, and health of Holstein dairy cows. J. Dairy Sci. $85: 1157-1164$

Reinhardt, T. A., J. D. Lippolis, B. J. McCluskey, J. P. Goff, and R. L. Horst. 2011. Prevalence of subclinical hypocalcemia in dairy herds. Vet. J. 188:122-124.

SAS Institute. 2009. SAS User's Guide: Statistics. Version 9.2. SAS Inst. Inc., Cary, NC. 
Shaver, R. D. 1997. Nutritional risk factors in the etiology of left displaced abomasums in dairy cows: A review. J. Dairy Sci. 80:24492453.

Sivertsen, T., G. Øvernes, O. Østerås, U. Nymoen, and T. Lunder. 2005. Plasma vitamin E and blood selenium concentrations in Norwegian dairy cows: Regional differences and relations to feeding and health. Acta Vet. Scand. 46:177-191.

Sordillo, L. M., and S. L. Aitken. 2009. Impact of oxidative stress on the health and immune function of dairy cattle. Vet. Immunol. Immunopathol. 128:104-109.

Stengärde, L., K. Holtenius, M. Tråvén, J. Hultgren, R. Niskanen, and U. Emanuelson. 2010. Blood profiles in dairy cows with displaced abomasums. J. Dairy Sci. 93:4691-4699.

Traber, M. G., and J. Atkinson. 2007. Vitamin E, antioxidant and nothing more. Free Radic. Biol. Med. 43:4-15.

Traber, M. G., and I. Jialal. 2000. Measurement of lipid-soluble vitamins - Further adjustment needed? Lancet 355:2013-2014.

US Department of Agriculture. 2009. Dairy 2007, Part I: Reference of Dairy Cattle Health and Management Practices in the United States, 2007. US Department of Agriculture-Animal and Plant Health Inspection Service-Veterinary Services, Centers for Epidemiology and Animal Health (USDA-APHIS-VS-CEAH), Fort Collins, CO.
Vogel, K. D., J. R. Claus, T. Grandin, G. R. Oetzel, and D. M. Schaefer. 2011. Effect of water and feed withdrawal and health status on blood and serum components, body weight loss, and meat and carcass characteristics of Holstein slaughter cows. J. Anim. Sci 89:538-548

Weiss, W. P. 1998. Requirement of fat-soluble vitamins for dairy cows: A review. J. Dairy Sci. 81:2493-2501.

Weiss, W. P., J. S. Hogan, K. L. Smith, and S. N. Williams. 1994. Effect of dietary fat and vitamin $\mathrm{E}$ on $\alpha$-tocopherol and $\beta$-carotene in blood of peripartum cows. J. Dairy Sci. 77:1422-1429.

Weiss, W. P., J. S. Hogan, D. A. Todhunter, and K. L. Smith. 1997. Effect of vitamin E supplementation in diets with a low concentration of selenium on mammary gland health of dairy cows. J. Dairy Sci. 80:1728-1737.

Weiss, W. P., J. S. Hogan, and D. J. Wyatt. 2009. Relative bioavailability of all-rac and RRR vitamin E based on neutrophil function and total $\alpha$-tocopherol and isomer concentrations in periparturient dairy cows and their calves. J. Dairy Sci. 92:720-731.

Weiss, W. P., and D. J. Wyatt. 2003. Effect of dietary fat and vitamin $\mathrm{E}$ on $\alpha$-tocopherol in milk from dairy cows. J. Dairy Sci. 86:3582-3591. 